\title{
Perceptions of Food Waste Reduction in Sri Lanka's Commercial Capital, Colombo
}

\author{
Maren Reitemeier, Mohamed Aheeyar (D) and Pay Drechsel *
}

International Water Management Institute (IWMI), Battaramulla 10120, Sri Lanka; Maren.Reitemeier@googlemail.com (M.R.); M.Aheeyar@cgiar.org (M.A.)

* Correspondence: P.Drechsel@cgiar.org

Citation: Reitemeier, M.; Aheeyar, M.; Drechsel, P. Perceptions of Food Waste Reduction in Sri Lanka's Commercial Capital, Colombo. Sustainability 2021, 13, 838. https:// doi.org/10.3390/su13020838

Received: 28 November 2020 Accepted: 12 January 2021 Published: 16 January 2021

Publisher's Note: MDPI stays neutral with regard to jurisdictional clai$\mathrm{ms}$ in published maps and institutional affiliations.

Copyright: (C) 2021 by the authors. Licensee MDPI, Basel, Switzerland. This article is an open access article distributed under the terms and conditions of the Creative Commons Attribution (CC BY) license (https:// creativecommons.org/licenses/by/ $4.0 /)$.

\begin{abstract}
In 2019, Sri Lanka introduced two policies that referred to food waste and the need to reduce it. To understand key stakeholders' readiness in this context, this study analyzed the food waste perceptions of private and public sectors in Colombo (open markets, supermarkets, hotels, restaurants, canteens, food caterers and key authorities). Interviews were carried out with operational managers and public officials, as well as other stakeholders who have roles in food waste redistribution and reuse, such as NGOs and the livestock sector. So far, the food-waste-related policy recommendations lack an operational inter-institutional home which can build on measures, like standards, regulations and incentives. Thus, most food waste reduction initiatives are initiated by NGOs or by the private sector, e.g., by larger hotels and supermarket chains. These entities were ready to lead by example, based on the understanding that urban food waste is an internal (financial) management challenge. Among smaller local entities, food waste was perceived more as an external issue to be handled by the city's waste collection services. Although perceptions varied between entities generating smaller or larger quantities of food waste, there was general agreement that suboptimal capacities and mechanisms to quantify, monitor and cost food waste generation appeared to be obstacles for in-depth awareness creation and action. There was significant interest in communication platforms for cross-sectoral learning, win/win collaborations with reliable collection (reuse) services that are currently operational, such as those provided by piggeries, as well as surplus redistribution initiatives if food safety and related liabilities can be addressed effectively.
\end{abstract}

Keywords: South Asia; stakeholder perceptions; food waste management; surplus food redistribution; animal feed; landfill collapse

\section{Introduction}

Food security is a major concern in many developing countries. Food production must clearly increase significantly to meet the future demands of the increasing global population. One thrust to fight imbalances and reduce tensions between consumption and production demands is to promote the mitigation of food loss and food wastage and thus improve the efficiency of the whole food chain [1]. The aim of Goal 12 of the United Nations (UN) 2030 Agenda for Sustainable Development is to "ensure sustainable consumption and production patterns". Its stated targets are to "halve per capita global food waste at the retail and consumer level, and reduce food losses along production and supply chains by 2030" [2]. Reducing food waste has consequently been included, e.g., within the European strategy for the circular economy. The adoption process is much slower in low-income countries, where food waste is only a component of the larger solid and liquid waste management challenges that especially urban areas face [3]. While the reduction of food loss is a traditional agricultural policy objective guiding pre- and post-harvest management in rural areas, the challenge of food waste management is most obvious in urban areas which are over-proportional food waste producers but which are also the most innovative in tackling the related challenges. It must be noted that definitions of food loss 
and waste (FLW) differ among stakeholders. A common distinction supported by different UN organizations is that food loss is the decrease in edible food mass in the production, post-harvest and processing stages, whereas food waste is food loss that occurs during wholesale, retail or final consumption [1].

According to the Food and Agriculture Organization (FAO), Central and Southern Asia are the globally leading food waste producers [2]. In Sri Lanka, public attention was galvanized in 2017 when the 46-m-high inner-city Meethotamulla garbage dump collapsed, destroying 146 houses and 32 lives in Colombo (https:/ / roar.media/english/life/in-theknow/meethotamulla-one-year-on). The Meethotamulla incident resulted in a strong, multi-agency effort to improve solid waste management operations from generation to disposal, including a powerful push for waste segregation at the source. This widespread campaign is being led by the national government in association with local authorities, focusing on messaging (and actions) that unsegregated waste will not be collected from residential or commercial premises [4].

Food waste reduction is now part of the National Waste Management Policy, 2019, and the National Policy on Sustainable Consumption and Production (NPSCP), 2019 (Box 1). The latter has adopted the Sustainable Development Goal (SDG) 12.3 targets. However, the effectiveness of these policies largely depends on how they will be transformed into local by-laws, regulations, educational campaigns and, e.g., fiscal incentive systems, and consequently implemented by the mandated agency and its stakeholders. Existing regulatory mechanisms still lack an integrated and comprehensive approach to addressing food waste challenges along the food value chain. For example, in 2020, the Negombo Municipal Council published a Waste Management Strategy and Action Plan, which calls for the preparation of a food waste reduction plan only as a long-term priority [5].

Box 1. National policies on food waste in Sri Lanka.

\begin{tabular}{|c|}
\hline $\begin{array}{l}\text { National Waste Management Policy (revised 2019) } \\
\text { Under its section on 'Food, Agriculture and Livestock Waste' this policy calls for (a) comprehensive strategies } \\
\text { and action plans to be developed by the ministries of agriculture, trade, tourism, local government, health and } \\
\text { education to minimize the amount of food, agricultural and livestock waste for disposal, in collaboration with } \\
\text { the relevant stakeholders; (b) relevant leading agencies shall monitor and record waste management periodically } \\
\text { and report to the Ministry of Environment annually for a performance review. Concerning liquid waste from } \\
\text { kitchens, the policy stresses the importance of waste minimization and that waste generators shall be held } \\
\text { responsible for the prevention of health and environmental problems. Finally, the policy recommends that life } \\
\text { cycle thinking shall be incorporated into educational curricula from the primary level up to tertiary levels with } \\
\text { special emphasis on e-waste, food waste and waste arising from packaging. http://mmde.gov.lk/web/images/ } \\
\text { pdf/2018/nationalwastemanagementpolicy-english.pdf }\end{array}$ \\
\hline $\begin{array}{l}\text { National Policy on Sustainable Consumption and Production (2019) } \\
\text { This policy references the food waste hierarchy and adopts Sustainable Development Goal 12.3's target to } \\
\text { halve per capita global food waste at the retail and consumer levels and reduce food losses along production } \\
\text { and supply chains, including post-harvest losses. The policy aims to reduce food losses in the supply chain } \\
\text { (pre-/post-harvest) by } 10 \% \text { by } 2020 \text { and another } 20 \% \text { by } 2030 \text { and to reduce food waste by } 10 \% \text { by } 2020 \text { and } \\
\text { another } 20 \% \text { by } 2030 \text {. https:// www.switch-asia.eu/site/assets/files/2159/scp_national_policy_sl.pdf }\end{array}$ \\
\hline $\begin{array}{l}\text { National Agriculture Research Policy and Strategy (2018-2027) } \\
\text { 'Food Waste Management' is mentioned under 'Cross-Cutting Research Policy Areas' with the recommendation } \\
\text { "to promote sustainable methods to manage agricultural waste". It also calls for ensuring zero waste (such as } \\
\text { for fish and fisheries products). http:/ / www.slcarp.lk/wp-content/ uploads/2018/06/Research-Policy.pdf }\end{array}$ \\
\hline $\begin{array}{l}\text { National Agriculture Policy (2007) } \\
\text { In its section on 'Post Harvest Technology' this policy includes the traditional recommendation to develop and } \\
\text { promote better harvesting, processing, value addition, storage and transport methods to minimize pre- and } \\
\text { post-harvest losses to meet domestic and export market demands. http:/ / extwprlegs1.fao.org/docs/pdf/srl1 } \\
69600 . p d f\end{array}$ \\
\hline Source: [6] \\
\hline
\end{tabular}

The Western Province of Sri Lanka that hosts the city of Colombo houses approximately $30 \%$ of the country's total population. The population is expected to increase from 5.8 million to 9 million by 2030 [7]. Food waste is a growing problem, given the changes that 
food systems are undergoing due to rapid urbanization, higher urban income, expansion of supermarket chains and changes in diets and lifestyles.

About $60 \%$ of Sri Lanka's municipal solid waste (MSW) is generated in the Western Province, where Colombo District contributes 50\% (2100 t/day), and within the district the Colombo Municipal Council (CMC) accounts for $700 \mathrm{t} /$ day or $10 \%$ of the national total. This is produced on less than $1 \%$ of the country's land area [8]. Food waste constitutes approximately $50 \%$ of the solid waste generated in the country, but can also reach up to $69 \%$ [9-11]. Although primary food waste sources in Colombo are households, about $42 \%$ is generated by restaurants, markets and abattoirs/meat shops [8]. Data on food retail are lacking but some primary data can be found for schools, hotels, universities, hospitals and institutional canteens [11-13]. Retailers, however, are crucial in shaping both the behaviors of upstream food chain actors and the preferences of consumers. Moreover, they have a role in ensuring that a portion of products discarded at the retail level is still suitable for human or animal consumption [14].

Food waste can be avoided in various ways or re-purposed before expiry for the benefit of the food insecure. In fact, about $22 \%$ of the total population in Sri Lanka does not have sufficient food to sustain a healthy life and $33 \%$ of the people cannot afford a nutritious diet [15]. Other research has indicated that 7.6\% of Sri Lanka's population is undernourished and $15.1 \%$ and $17.3 \%$ of children under five years suffer from wasting and stunting, respectively [16]. Interestingly, these households are not limited to rural areas. Despite a low average poverty rate, the Western Province has the largest absolute number and percentage of food insecure people in the country [8]. Therefore, there is an urgent need for a reduction in - and redistribution of-avoidable food waste in urban Sri Lanka-ultimately supporting SDG 12.3 , while supporting the targets of reducing poverty (SDG 1) and enhancing food and nutrition security (SDG 2).

The commitment of the CMC to addressing the food waste challenge was confirmed in the signing of the Milan Urban Food Policy Pact (www.milanurbanfoodpolicypact.org/), which also includes progress indicators for food waste reduction. The question, however, is how far this commitment remains theoretical or whether it can be translated into practice.

This study initially adopted the food waste hierarchy (www.epa.gov/sustainablemanagement-food/food-recovery-hierarchy) as its framework [17] for the exploration of solutions, and the analysis of the results was mostly guided by Närvänen et al. (2020) [18], who presented an applied framework for managing food waste, including food surplus (surplus food is the edible food that is produced, manufactured, retailed or served but for various reasons is not sold to or consumed by the intended customer, calling for strategies of 'donation', 'redistribution', 're-use' or 'recovery'). This framework is based on four pillars for problem solving: (a) changing the behavior of actors, (b) connecting actors and activities within systems, (c) addressing sociocultural contexts and (d) identifying innovative solutions for food waste reduction, which all relate well to the context of urban Sri Lanka.

To delve deeper into the 'wicked food waste problem' [18] this study analyzes food waste perceptions of businesses in Colombo and its food retail and food service sectors (open markets, supermarkets, hotels, restaurants, canteens, catering and so forth). This particular focus was encouraged by a forthcoming FAO-led project on food waste in Colombo. Interviews were carried out with operational managers, authorities and other stakeholders who play or could play a role in food waste generation, collection, redistribution and also reuse, such as the livestock or piggery sectors.

The main research questions addressed in the study are:

(a) What is the level of food waste awareness in selected food entities and authorities?

(b) What are the managerial attitudes on food waste reduction strategies for 'walking the talk'?

(c) What are the drivers and constraints for assessing and reducing food waste and the implementation of food waste reduction strategies by stakeholders across scales? 


\section{Materials and Methods}

The study adopted a qualitative sampling approach based on key informant interviews (KIIs) from various food sectors using structured questionnaires (Table 1) to elicit reactions and information from key stakeholders on the research questions stated above. KIIs were conducted among the three main stakeholder groups, namely regulatory authorities, food waste generators and re-users of surplus food and commercially unfit food (also called 'former foodstuff', i.e., safe food which cannot be sold as it has, e.g., a transport damaged package), including piggery farmers. After an expert consultation and web-based stratification of these three groups of entities, key informants to represent each group were selected purposively. The purposive sampling ensured the inclusion of key stakeholders in all selected subcategories such as the main supermarket chains, leading hotels, open markets/fairs of different sizes and the different regulatory agencies. Purposive sampling was applied when the groups in these subcategories were small (Table 1), otherwise random sampling was used. In such cases, such as for piggery farmers, the sampling frame was prepared using contacts provided by the food entities and institutional canteens working with livestock farmers and also the farmer list maintained by the National Livestock Development Board (NLDB). Finally, matchmaking discussions between food waste suppliers and rescuers were initiated, using a checklist of topics, while allowing a free flow of arguments. Interviews were conducted between December 2018 and May 2019, except for those with the pig farmers, which were delayed due to COVID-19 and took place by phone mid-2020 due to restrictions for fieldwork. The sample size per category is shown in Table 1.

Table 1. Overview of stakeholder categories, sample size and purpose of selection.

\begin{tabular}{|c|c|c|c|c|}
\hline Stakeholder Category & & categories & $n$ & Purpose of the Interview \\
\hline \multirow{9}{*}{$\begin{array}{l}\text { Food waste } \\
\text { generators } \\
\text { (business sector) } \\
n=47\end{array}$} & \multirow{6}{*}{ Service sector } & Local cuisine & 9 & \multirow{9}{*}{$\begin{array}{l}\text { To investigate business } \\
\text { awareness of food waste } \\
\text { generation, reduction options } \\
\text { and entailed perceptions }\end{array}$} \\
\hline & & International cuisine & 9 & \\
\hline & & 4-5-star hotels & 5 & \\
\hline & & 2-3-star hotels & 4 & \\
\hline & & Canteens/catering & 4 & \\
\hline & & Bakeries and fast-food chains & 4 & \\
\hline & \multirow{3}{*}{$\begin{array}{l}\text { Retail } \\
\text { sector }\end{array}$} & Local shops & 5 & \\
\hline & & Supermarket chains & 4 & \\
\hline & & Open markets/fairs & 3 & \\
\hline \multirow{4}{*}{$\begin{array}{l}\text { Users of food } \\
\text { surplus and wasted } \\
\text { edible food } \\
n=29\end{array}$} & \multicolumn{2}{|l|}{ Food processors } & 2 & \multirow{4}{*}{$\begin{array}{l}\text { To understand operations, } \\
\text { motivations, challenges and } \\
\text { options for capturing wasted } \\
\text { edible food for reuse }\end{array}$} \\
\hline & \multicolumn{2}{|c|}{ Food rescue initiatives } & 2 & \\
\hline & \multicolumn{2}{|l|}{ Livestock farmers } & 24 & \\
\hline & \multicolumn{2}{|c|}{ Contracted collectors } & 1 & \\
\hline $\begin{array}{l}\text { Regulatory } \\
\text { agencies } \\
n=4\end{array}$ & \multicolumn{2}{|c|}{$\begin{array}{l}\text { Western Province Waste Management Authority (WMA) } \\
\text { Central Environmental Authority (CEA) } \\
\text { Colombo Medical Office of Health } \\
\text { National Livestock Development Board (NLDB) }\end{array}$} & 4 & $\begin{array}{l}\text { To learn about the regulatory } \\
\text { environment and problem } \\
\text { perceptions by authorities }\end{array}$ \\
\hline $\begin{array}{l}\text { External } \\
\text { organization } \\
n=1\end{array}$ & \multicolumn{2}{|c|}{$\begin{array}{l}\text { Food and Agriculture Organization (FAO); Sri } \\
\text { Lanka Office }\end{array}$} & 1 & $\begin{array}{l}\text { To understand which } \\
\text { facilitation an external party } \\
\text { can offer }\end{array}$ \\
\hline
\end{tabular}

Where possible, semi-quantitative analysis was attempted, with the note of caution that the limited number of interviews sets natural limits to the analysis. All interviews were managed via appointments, explaining the objectives of the project, and obtaining the consent of participants. Interviews used semi-structured guidelines based mostly on 
qualitative research principles. The questions addressed both challenges faced as well as potential solutions, covering food sourcing, the impact of food waste on the business, existing food waste management strategies if any, and alternative options/ideas on food waste prevention and reduction. Aside from the perception study, information on the entity's operations, including their challenges and outlooks, was gathered. For this reason, $75 \%$ of the interview partners were in a senior managing position, if not the owner of the entity. Managers of the food entities were addressed on purpose because of the questions referring to the managerial attitudes towards food waste reduction strategies. Those strategies need to be approved and launched by the decision-makers of the entity. Therefore, interviewing managers was crucial in order to obtain the results. It became apparent in the cases where we were directed to lower-ranking staff that they were in most cases not able to answer the interview questions; which is a result on its own.

Where possible, interviews were conducted in English, otherwise they were translated into the local language (Sinhala or Tamil). Face-to-face interviews were the preferred option unless the stakeholders were short on time and asked for phone interviews. Entity groups were ranked based on the average number of ongoing and planned initiatives for food waste reduction.

The focus group discussions brought together waste generators and re-users of wasted edible food (surplus donation and redistribution) to understand the practical challenges and opportunities of ongoing and potential matchmaking partnerships.

\section{Limitations/Reflections on Applied Methods}

Conducting the interviews in the managers' offices allowed limited insights into the food operations. Thus, the context of discussed aspects, such as where, why and what type of food is wasted, was often lacking. Participatory or anonymous observations of personnel in stores or kitchens could have been a supporting approach, as used, e.g., by Kumara et al. (2018) [19]. Including the employees in the interview scheme might have offered additional insight, e.g., a comparison of the employees' attitudes with those of the managers. However, this approach was eventually dismissed as it could have challenged internal hierarchies, or staff would have been briefed by their managers. It was initially argued that knowing the business-specific quantities of generated food waste and its value could greatly support the discussion with those stakeholders, as emphasized, e.g., by Eriksson (2015) [20]. On the other hand, it was useful to see if such assessments were already done or planned, and if not, why? Finally, compromises were needed in the selection of entities and the number of interviews due to time and resource constraints.

\section{Results and Discussion}

As food waste has only recently become a topic of public interest in Sri Lanka, the related policy framework is still rudimentary and missing strategies and action plans. The situation is very different in many other countries, in particular the European Union (EU), but also in countries like Argentina and Chile [2,7,21,22]. In Chile, for example, an action plan for 2018-2019 was prepared by public institutions and private organizations focusing on three pillars: (i) governance; (ii) information and communication; and (iii) research, technology and knowledge required to reduce food loss and waste. As part of the Argentinian program, the national campaign named "Valoremos los Alimentos" provides information and videos on how to prevent food loss and waste [2].

However, while the public sector might still have to catch up, food waste reduction is first of all a private and domestic sector call. This section will describe the awareness of the food waste challenge among the stakeholders interviewed (Section 3.1), followed by the reported food waste prevention and reduction strategies (Section 3.2). Section 3.8 will look at the recovery of food waste, including commercially unfit food for livestock feeding, and Section 3.9 will cover food waste recycling within the premises or by the local authority. Finally, Section 3.10 will briefly touch on the demand for stakeholder platforms and information sharing. 


\subsection{Perceived Relation between Food Waste and Business}

These findings are based on the results of the interviews conducted with the retail market and food services sectors $(n=47)$. From the responses to the first question: "How does food waste affect your business?" the perceived food waste situation could be grouped into three inductively formed categories based on the answers given by the respondents(i) satisfied with the current situation (30\%), 'struggling to manage' $(59 \%)$ and 'seeing food waste as part of the business' (20\%) (Figure 1). Due to multiple responses provided by the respondents, the total sum of the answers can be more than $100 \%$ and therefore the distinct characterization of the groups was not possible. For example, some entities who recognized food waste as a challenge had also realized certain aspects in their business operation, such as an inedible food share, as unavoidable (part of the business).
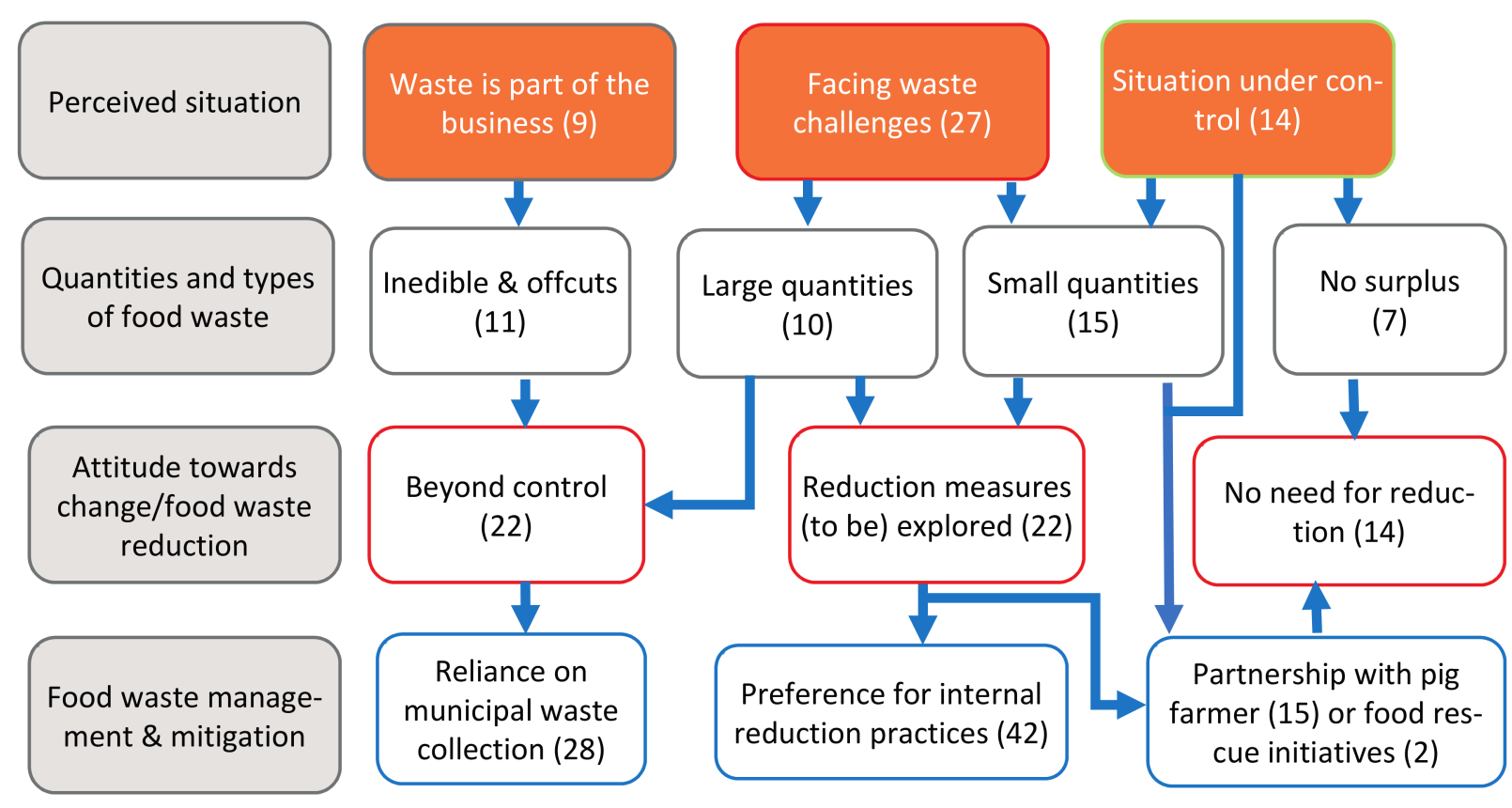

Figure 1. Semi-quantitative visualization of stakeholder perceptions on food waste generation and their interlinkages. Numbers in brackets represent entities answering in support of the respective statement.

The discussions held with the stakeholders related to food services indicates that they are in general keen to improve resource use efficiency in their businesses, like adopting energy and water-saving technologies to cut costs, but remain less engaged in view of food waste prevention and reduction strategies. The majority of smaller businesses in particular were not cognizant of the food they were wasting and perceived food waste as inevitable or unavoidable and therefore as an acceptable practice, similar to what Hebrok and Boks (2017) [23] reported for consumers. However, even when larger restaurants, for example, accepted food waste as a challenge, a mixed perception vis-à-vis waste reduction was observed, largely linked to the fear that if one actor is willing to make changes towards food waste prevention and reduction, competitors might not do so, and offer more food, or accept more plate leftovers for the larger benefit of pleasing a potentially returning customer. Similar findings were also reported from the tourist sector, where the awareness of the need to minimize food wastage is high among hotel management, and accompanied by efforts to reduce costs through food waste minimization [12]. However, hoteliers also have faced various challenges mainly due to the perception and behavioral patterns of customers, which they declared to be beyond their control.

Across the interviews, financial considerations were found to be the most effective driving factor to address food waste. According to our interviews, the average economic loss for supermarkets due to food waste was estimated to be about LKR 216,000 +/ - 114,002 per month and outlets across four analyzed chains [19]. However, only one supermarket 
chain had estimated the annual financial impact of wasting food at nearly LKR 600 million per year across all its outlets, which equals ca. three million euros. In a smaller bed and breakfast hotel, on the other hand, the amount of waste is of no financial concern. Other entities were content with their situation as they had already outsourced their waste disposal problem to pig farmers or allowed employees to consume surplus food. Aside from the cost/benefit ratio of food waste reduction interventions, social and environmental motivations (triple bottom line) were also expressed, in particular in larger companies with corporate social responsibility (CSR) targets.

There was a clear indication that in entities aiming for international standards, certificates and green awards (larger hotels, supermarket chains, international cuisine restaurants), food waste was perceived more as a management (cost) challenge that needed to be addressed, whereas in smaller or more local entities food waste was rather perceived as an end-of-business challenge for the city's waste collection service. There also appears to be a direct correlation between the perceived need for change and the declared quantity of generated food waste. Consequently, in entities where no large amounts of surplus food are discarded, participants did not see much potential in implementing particular strategies. However, hardly any of these entities had data to verify their assumptions. One restaurant with an international kitchen even stated as an answer to the question of whether they measured their food waste: "No. Should we?". It was observed that the absence of a capacity and mechanism to measure and monitor the food waste generated appeared to be one of the reasons for missing action, as expressed by another restaurant. "So, this year we wanted to find a way to kind of measure our waste and see how we can move forward with that. And I mean, it is easier said than done. It is hard for us, to know where to start with that". Fortunately, Sri Lanka does not have to reinvent the wheel and can learn, e.g., from European experiences [24]. Guidelines and tools, e.g., for food waste prevention, reduction and costing exist (see, e.g., the Waste and Resources Action Programme at wrap.org.uk) and can help to develop and adopt a standardized methodology for a monitoring plan and reporting mechanism in support of SDG 12.3. Care has to be taken that the system matches the technologies available as- e.g., real-time digitization is not a common option in Sri Lanka's food sector.

Figure 2 shows a tentative ranking of the interviewed entities based on the average number of ongoing and planned internal initiatives for food waste reduction. Most initiatives were recorded in the top-ranking green segments. Even in the low ranking group of local retailers, entities were using, e.g., fruit surplus for juice production, or partnerships with pig farmers among local restaurants, which reflects a general awareness.

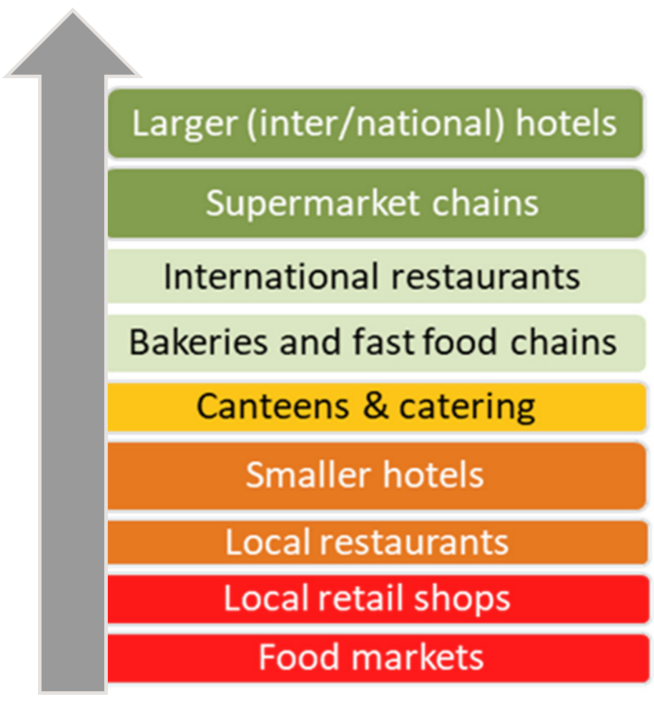

Figure 2. Ranking of interviewed entities in view of existing initiatives and interest in reducing food waste (green $=$ top ranking). 


\subsection{Food Waste Prevention and Reduction Strategies}

Challenges and strategies mentioned can be grouped into the areas of food supply, demand forecasting, food preparation, buffet and portion management, surplus management and staff training and awareness creation. The most commonly expressed solutions are shown in Table 2.

Table 2. Commonly expressed challenges and solutions by Sri Lankan food entities.

\begin{tabular}{|c|c|c|c|c|c|}
\hline & $\begin{array}{c}\text { Food } \\
\text { Supply }\end{array}$ & $\begin{array}{c}\text { Storage \& } \\
\text { Preparation }\end{array}$ & Sale \& Service & $\begin{array}{c}\text { Food } \\
\text { Consumption }\end{array}$ & Waste Collection \\
\hline $\begin{array}{l}\text { Challenges } \\
\text { mentioned }\end{array}$ & $\begin{array}{l}\text { Limited control of } \\
\text { quality received } \\
\text { Transport } \\
\text { damages }\end{array}$ & $\begin{array}{c}\text { Capacity limitations } \\
\text { (know-how \& } \\
\text { facilities) } \\
\text { Hot climatic } \\
\text { conditions }\end{array}$ & $\begin{array}{c}\text { Demand } \\
\text { uncertainties } \\
\text { Surplus due to full } \\
\text { buffet / full shelf } \\
\text { expectations }\end{array}$ & $\begin{array}{c}\text { Plate leftovers } \\
\text { from guests \& staff }\end{array}$ & $\begin{array}{l}\text { Unreliable } \\
\text { collection service } \\
\text { and food waste } \\
\text { starts to rot }\end{array}$ \\
\hline $\begin{array}{l}\text { Solutions } \\
\text { mentioned }\end{array}$ & $\begin{array}{l}\text { Alternative (own) } \\
\text { contracts with } \\
\text { suppliers \& } \\
\text { farmers } \\
\text { Use of multiple } \\
\text { sized crates } \\
\text { Returning } \\
\text { questionable } \\
\text { quality instantly }\end{array}$ & $\begin{array}{l}\text { Staff trainings and } \\
\text { awareness creation } \\
\text { Improved cooling } \\
\text { facilities } \\
\text { Menu designing \& } \\
\text { value-added } \\
\text { processing with } \\
\text { off-cuts and surplus } \\
\text { stock }\end{array}$ & $\begin{array}{c}\text { Dedicated } \\
\text { forecasting \& } \\
\text { monitoring system } \\
\text { Offer price } \\
\text { discounts } \\
\text { Permission for } \\
\text { staff to consume } \\
\text { surplus } \\
\text { Surplus donation } \\
\text { to redistribution } \\
\text { initiatives }\end{array}$ & $\begin{array}{c}\text { Awareness } \\
\text { creation (weighing } \\
\text { of plate waste) } \\
\text { Informing guests } \\
\text { about portion sizes } \\
\text { and } \\
\text { take-home } \\
\text { Offer smaller } \\
\text { dishes at } \\
\text { buffet }\end{array}$ & $\begin{array}{l}\text { Agreement with } \\
\text { pig famers for } \\
\text { daily (non- meat) } \\
\text { food waste } \\
\text { collection } \\
\text { (feedstock) } \\
\text { Support of private } \\
\text { sector composting }\end{array}$ \\
\hline
\end{tabular}

\subsection{Sourcing High-Quality Food and Offering Promotional Discounts}

The most often mentioned challenge mentioned in the service and retail sector was limited control over the food delivered. On the other hand, about $1 / 3$ of the respondents mentioned that this can be addressed contractually, allowing them careful sourcing of high-quality food products. According to the expressed experience, food waste can be reduced by up to $50 \%$ through this approach. While careful sourcing appears to be a good strategy for the food entity, the supplier needs a secondary market to sell the stock which was rejected by the retailer/supermarket or hotel, or use similar criteria when sourcing. The most popular strategy adopted by the retail sector to avoid food waste at the sales end is providing promotional discounts for food items nearing their expiry date. One of the popular supermarket chains in Colombo declared that they were able to save $400,000 \mathrm{~kg}$ of food items every quarter by promotional discounts; otherwise, the items would have been discarded. The research found significant attention to the waste challenge in general, and food waste in particular, in particular by some of the leading chains.

\subsection{Forecasting and Monitoring Demand}

The system of stock forecasting of food was described as a powerful tool by half of the food waste generators (mostly in the restaurant, catering and hotel sector), although demand fluctuations are considered a significant challenge for accurate forecasting. The challenge is higher for retailers and eateries, which can only estimate the demand based on past customer trends, whereas larger hotels have their guest lists and figures in advance. Where daily purchases are not feasible, hotels and restaurant managers pointed out that the amounts to be cooked have to be well calculated as the shelf life of prepared food is short. 
Recognized in the three main groups was the mutual policy of maintaining a security buffer of stock and prepared food items also in response to demand fluctuation and to meet customers' demand.

Internal live communication between various departments within the food entity, for example, between banquet and kitchen staff, was cited as a useful tool for monitoring demand and preventing surplus production.

\subsection{Food Preparation, Buffet and Portion Management}

In many restaurants, the menus are set up to include multiple dishes that are prepared using the same ingredients, which help to minimize potential food waste in the kitchen. Another strategy adopted is use of vegetable, fish and meat off-cuts for value-added dishes like soups and salads. Some of the hotels and restaurants are using part of surplus uncooked food to make different types of pickles, marmalade jam and stocks.

In some cases, the kitchen was managed well, but the plate leftovers from consumers represented the most significant share of waste in foodservice entities next to overproduction. A dominant cause for plate waste generation is buffet service, as customers tend to pile up their plates. Improvements of buffet settings, such as an adjusted refill rate, were mentioned by almost all hotel managers and restaurants with buffet service. Despite such efforts, buffets remain as attractive as they are wasteful, as also reported from the service sector in very different cultures $[25,26]$. This is being addressed by some restaurant buffets or canteens, which offer customers portions, especially rice portions, based on demand or through charging portions by weight. Batch-wise cooking is practiced in larger buffet events in bigger hotels by careful monitoring of the food movement of different items in the buffet during the event.

What remains eventually on the plate is considered to be outside the control of hotel staff. A study conducted in the Spanish foodservice sector by Derqui et al. (2016) [27], describes similar attitudes of the interviewees towards consumer leftovers. As stated, food waste occurring before serving affects the profit and loss statements of food entities directly, which initiates the motivation for reduction, unlike post-consumption food waste.

\subsection{Staff Training and Awareness Creation on Food Waste Prevention and Reduction}

Innovative methods discussed, but still seldom implemented, could include, e.g., subtle communication strategies in restaurants, such as table cards or wall posters, to make customers aware of options for waste reduction while having a satisfying meal. Restaurants could indicate the size of servings in the menu card itself, as is common in pizzerias. Another option is to take the remaining à la carte food home (takeaway), which obviously cannot be applied to buffet food. The interviews showed, however, that some customers are reluctant to claim their leftovers, although restaurants do encourage especially local customers to pack and take home the uneaten portions, including obvious waste, like bones for pets (which does not apply to tourists or hotel guests). While awareness creation for customers was considered positively in 12 cases, the implementation of imparted knowledge remained restricted by cultural, financial and attitudinal reasons. Several interviewees stated that the satisfaction of customers has a much higher priority than reducing food waste, resulting in a 'competing priority', as also reported, e.g., in a study from Denmark [28].

As one manager explained, "It isn't that we can't, I guess we can, but it is considered rude if you go to a guest and say something". Event catering, such as during a week-long retreat or conference, allows more meaningful awareness campaigns, which was considered important as "customers need regular reminders; they aren't going to change behavior based on a one- or two-day exposure".

Internal awareness creation and training were listed as central measures by about half of the interviewed entities, in particular hotels, international restaurants, and supermarket chains and some other businesses. Capacity needs identified by the respondents were related to skill enhancement in food preparation (e.g., appropriate methods to cut fruits 
and vegetables), food handling and plate waste management. Where training or awareness creation activities took place, key components mentioned by 19 entities were the assessing, monitoring and reporting of the amount of generated food waste (in kitchens). Classroom teaching was ranked low, whereas food-saving awards and motivational posters appeared to be more useful. There were mixed reflections to training conducted by outsiders, e.g., if local relevance was missing. The need of a more prominent role for local authorities like the Colombo Municipal Council was suggested for sensitization and awareness creation on food waste prevention and reduction. Missing support by authorities with tools like those published by USEPA $(2014 a, 2014 b)[29,30]$ was identified as a gap where action could be taken. The responses also indicated that internal training has to be accompanied by public awareness creation, for example, using social media to catalyze changes in attitudes and behaviors of stakeholders across the food sector.

\subsection{Surplus Management-Food Rescue Operations}

The strategies adopted to manage surplus food varies between entities, depending on the type of food and outlet. Some of the strategies expressed were returning the surplus to the supplier/main branch, distributing it to staff or re-purposing it. One out of the three supermarket chains interviewed preserved surplus fruits and vegetables in cold storage for value-added processing, such as the preparation of fruit salads or juices. In addition, dried fruits for export were mentioned as an option, given the low price of fresh fruit in Sri Lanka. Implementation challenges are related to quality certificates, machinery needed for special packaging, regulations and variations in supply.

Although in particular most local restaurants have no issue with distributing surplus food to employees, several entities feared that this could encourage staff to create food waste, and therefore it is not supported by supermarkets, larger hotels, and fast-food chains. The redistribution of overproduction or unsold food to needy people living in the vicinity has been practiced by several of the interviewed restaurants, canteens, bakeries, caterers and supermarkets. One of the major supermarket chains in Colombo revealed that they were donating, e.g., up to $1000 \mathrm{~kg}$ of surplus food items every week in 2019 to about $350+$ people. Even more successful examples of food banks have been reported from many other countries, including Southern Asia, such as in Malaysia (see e.g., www. foodaidfoundation.org/how-it-works.html and www.tesco.com.my/Our-Little-Helps / Projects /Tesco-Malaysia-Food-Waste-Data-2018-19/2019/ProjectDetails/) and Singapore (e.g., https://sgfoodrescue.wordpress.com/operations/). A common challenge in the case of Colombo is that the food redistribution, e.g., to orphanages, homeless people or nursing homes, either directly or through existing charity organizations, requires logistics. Food rescue initiatives with transport and cold storage capacity appear most useful as partners. In Colombo, a well-known non-profit initiative is the 'Robin Hood Army' (Box 2). Half of the food entity operators and authorities mentioned know of them from the press. However, only a small minority had started discussions about a possible collaboration.

While the CMC Medical Officer of Health did not see any regulatory barriers for starting a (social) business based on surplus food redistribution, concerns were expressed by the likely food donors. In the absence of safety and quality standards to assure the hygiene and safety of the distributed food, the donors feared reputational risks (bad press) and liability questions if the food was not reaching its target group as long as it was fresh and safe. Strict guidelines and possible disclaimers were discussed in the matchmaking interviews, aiming at a high level of transparency for any redistribution partnership. Differences between redistributing bakery products, cooked meals and finger food were acknowledged, as well as the fact that not every food fits all groups of society. A key challenge mentioned was the short time window between food release in the evening and food demand, e.g., by nursing homes, as well as the need of those homes to be sure that food would arrive in time. Thus, while some food would have to stay heated, other foods could be stored cold, both requiring infrastructure, which is still a barrier to overcome, as acknowledged by the charities involved in food redistribution. That is why their model 
builds strongly on an 'army' of volunteers who can transport any food offer as quickly as possible to the next place of demand. A similar challenge has been reported in Italy [31]. The authors found that food donors miss data on the optimal time to withdraw the products from the shelves, as well as the quantities to be donated to the non-profit organizations or those to be sent to the livestock market, maximizing the retailers' cost savings or profit [31].

Box 2. Objectives, operations and capacities of local food rescue initiatives.

To tackle the two coexisting social problems of food waste and hunger, the Sri Lankan branch of the Robin Hood Army (RHA) started its surplus food distribution service in Colombo in 2016. The RHA sticks to two policies, which are (i) not accepting monetary donations and (ii) being neutral towards religious beliefs. Although the focus is on food (surplus) waste, under COVID-19, RHA also helped to distribute flour, rice, dhal and tea to families in need. At the time of the interview in mid-2019, the RHA had 29 main distribution points, where donated food is brought, and was supported by 151 voluntary members. RHA provides food to roughly 4000 individuals on a monthly average. Their key partners are bakeries and occasionally restaurants, with excess food collected in the night by available volunteers, who are coordinated via social media ('WhatsApp') to collect/distribute food.

Another social initiative is 'The Soup Bowl' (SB), which started in 2015 with lunch packages for the homeless. After receiving funding and support, the initiators were able to scale the operations, e.g., with a weekly free lunch for around 100 people. On other days of the week, the SB collects unsold food from a supermarket chain. Respecting the limited shelf life of the saved products, these are directly transported to identified homes and not used for the weekly meals. For the meals, the quantities would also not be enough. The Soup Bowl has a core team of eight fixed members and several one-time helpers for the weekly actions.

Both initiatives struggle with the time limitations of their staff and volunteers, as well as missing infrastructure, such as refrigerated vehicles and storage facilities. Ideally, they prefer to directly link supply and demand given these limitations.

\subsection{Recovery of Food Waste for Livestock Feeding}

Use of food waste for animal feed is a higher-value alternative with fewer negative environmental impacts than composting, anaerobic digestion and landfill disposal [17]. Out of 46 interviewed food entities, 15 have a usual informal partnership with livestock farms. These are piggeries with 15 to 5000 animals. The analysis showed that 23 of 24 piggeries collected food waste, including commercially unsuitable food to feed for their animals. The daily collection rate varied between $50 \mathrm{~kg}$ to $10 \mathrm{t}$, with an average of $1480 \mathrm{~kg}$. About $30 \%$ of the farmers collected $50-100 \mathrm{~kg}$ of feed per day. The number of collection points per farmer varied from 2 to 20, depending on the quantity needed and collected. The surveyed farmers covered about $80 \%$ of the daily needs of restaurants, canteens, hotels, markets, etc. For this, farmers travelled on average $62 \mathrm{~km} /$ day to collect the required amounts. About a quarter of the farmers predominantly targeted hotels, whereas another quarter targeted institutional canteens. About $40 \%$ collected from multiple sources to meet their daily feed demand. The material was usually free. One in four farmers bought additional food waste from private intermediate traders at a rate of LKR 2 to 40 per $\mathrm{kg}$. Intermediate traders of food waste for piggeries have also been reported in Negombo [10], where approximately 1-2 tons/day of food waste is collected and sold.

One of the challenges faced by piggeries is the seasonal nature of the feed supply, especially from entities serving the tourist sector. Another challenge can be the quality of the collected food (e.g., mixed with packaging materials), which requires additional labor costs for organic waste segregation.

The expected advantages for the feed suppliers are a higher probability that food waste gets collected, bins returned clean and a more frequent (daily), reliable and free service. For transport time and cost reasons, farmers prefer to source only a few larger producers. Sourcing smaller entities or even households is not a viable concept, unless an arrangement is put in place to channel the smaller quantities to distinct collection points. 
Larger hotels have the additional advantage that they can keep their food waste in an air-conditioned room, which is also expected by law.

Several countries have put in place guidelines and regulations to ensure the safety and hygiene of distributed surplus food as animal feed. In the EU, for example, the use of catering waste in animal feed was prohibited in 2002 as a consecutive action after the foot-and-mouth disease outbreak in the United Kingdom in 2001, due to the feeding of uncooked food waste to swine [32]. In Sri Lanka, regulations necessitating the sterilization of collected feed material, such as through the boiling of any collected meat waste, are a common recommendation but are not compulsory, as confirmed by the chairman of the NLDB, and are also not uniformly implemented by the interviewed farmers.

\subsection{Food Waste Recycling within the Premises or by the Local Authority}

In the food recovery hierarchy, biogas generation and compost production are some of the last options to recover at least energy or soil nutrients and organic matter for crop production, respectively. The prospects of strengthening on- and off-site food waste treatment was discussed with 29 food entities and the directors of the Central Environmental Authority (CEA) and the Western Province Waste Management Authority (WMA). From the collective perspective of food entity operators, the assessed barriers of having an onsite food waste recycling facility were space in particular, possible odor, the attraction of animals and the need for trained staff. These disadvantages outweighed the possible benefits, although seven (usually larger) entities expressed interest in installing on-site biogas or compost plants or had even tried but struggled with space and regulatory obstacles. Only a few entities had a composting or biogas unit in place. From the perspective of the authorities, domestic composting or institutional biogas plants are encouraged. Such a move could be supported by 'green labeling' [33].

To facilitate off-site composting in Sri Lanka, source segregation (organic vs. inorganic waste) has been demanded by law since 2016, when the government published a Circular to encourage waste separation, particularly in the municipal councils. Segregation practices have been adopted by households since early 2017. Official data on household compliance are lacking, although it was reported that prior to the Meethotamulla disaster segregation rates were about $5 \%$, and then they skyrocketed to $42 \%$ [34].

About $95 \%$ of the food entities stated that their food waste was segregated and, if not absorbed by pig farmers, was collected by the municipal council for further treatment (e.g., composting at Kaduwela) or disposal. As segregated waste also ends up on landfill, different stakeholders expressed concerns about the lack of communication between authorities about alternative waste valorization strategies. "The emphasis on segregating garbage is good, but the problem is that there are not [large] enough compost facilities to absorb the organic matter" [35]. In the recycling center of Kaduwela, for example, space constraints demand that $60 \%$ of the delivered organic waste gets rejected for private landfilling or composting. The rejected non-biodegradable waste fraction is even far higher [36]. Therefore, strategies for the prevention and reduction of food waste generation in households and businesses should be the priority solution to address the waste problem at its roots and in a sustainable way.

\subsection{Inter-Institutional Coordination and Support Challenges}

As the interviews showed, most of the interested private and public stakeholders asked for communication platforms or channels to access know-how, tools or jointly lobby for a more a supportive enabling environment as seen, for instance, in the European Union [37]. The 2019 National Waste Management Policy recognized the need for such inter-agency communication by calling upon six ministries to join hands for food waste reduction (see Box 1). This, however, takes time. At an intermediate scale between local stakeholders and national ministries, the municipal councils could play a key role. However, even in Colombo, there is no authority in charge of urban food supply or food waste reduction. Only the departments for Public Health and Veterinary Services address food, mainly 
in view of food safety, e.g., through monitoring food expiry dates. Furthermore, the authorities working on organic waste, like CEA and WMA, and the waste management departments at the council level, have so far not dealt with food waste before it enters the bin and gets collected. As stated by the CEA, "we have not paid that much attention to food waste per se until the adoption of the latest National Waste Management Policy of 2019 and National Policy on Sustainable Consumption and Production (NSCPP) of 2019". The National Policy on Sustainable Consumption and Production identified the Ministry of Agriculture as the lead ministry for achieving the SDG 12.3 targets. However, the strength of that ministry is traditionally more at the start of the food chain. Thus, the Ministry in charge of Environment has been assigned to guide the implementation and monitoring of the SDG 12 strategies and measures and to handle all operations, including communications, reporting, awareness raising and capacity building. The Ministry, which has experience with the green reporting system and procurement, proposed in 2019 a 5-Year Action Plan on Minimization of Food Waste (2019-2023), subject to funding. This offered an opportunity for the FAO to assist with an action plan for urban Sri Lanka [38]. Given the more urban focus, the main national project partner is the Ministry of Urban Development, showing again the complexity of the institutional challenges. However, the FAO initiative also shows the catalyzing function of 'third sector' actors [18], including those who are traditionally more engaged in addressing food insecurity than reducing food waste.

\section{Conclusions}

The institutional complexity in addressing the food waste challenge in Sri Lanka could be considered an example of a wicked problem within the larger challenge of appropriate waste and sanitation services $[3,18]$. Although there is no dedicated policy on food waste in the country, a supportive policy framework is emerging. To date, however, the related recommendations lack detailed guidance regarding priorities along the food chain or within the waste prevention hierarchy. While countries will continue to differ in their approach to tackling food waste [21-23,39], standards and targets have to be defined and supported in one way or another, such as through market-based or fiscal incentives, regulatory measures, capacity development and most of all an inter-institutional structure that is able to coordinate a national program across all scales. This is a work in progress. The National Waste Management Policy acknowledges that food waste requires a multi-institutional effort, which however carries the risk that its management might fall through the cracks without a well-empowered institutional home. In this present scenario, the food waste prevention (recovery) hierarchy will remain academic, and mostly upside-down, with the highest volume of food waste being disposed, followed by public sector composting, some redistribution to animals and finally prevention, which is so far only fully institutionalized in highly commercial entities (upper part of Figure 2). However, with more awareness creation and practical support, food waste prevention options could also reach public canteens of hospitals, universities and schools, for example, or medium size enterprises of the food service sector based on expressed interest.

A key question is on the leadership at the municipal level. As mentioned above, in the Colombo Municipal Council, food supply and food waste prevention or reduction have no real administrative home. Such institutional gaps can be addressed, however. The city of Negombo, close to Colombo, translated the NSCPP into its own Waste Management Strategy and Action Plan. The strategy adopted the waste management hierarchy with its $3 R$ principle of Reduce, Reuse and Recycle and set even more progressive organic waste reduction targets for 2022, 2025 and 2030 than the SDG 12.3-guided NSCPP itself [5]. This plan was facilitated by the UN Environmental Program (UNEP), indicating the added value of third party support, similarly to the FAO initiative referenced above. The plan puts significant emphasis on composting at the household and community scale. As Sri Lanka has a well-established national network of more than 100 compost stations [40], restrictions on the landfill disposal of organic waste towards a step-wise implementation of a landfill ban, at least for larger food waste producers, could drive food enterprises to 
explore more sustainable practices, such as source reduction, donation, composting and anaerobic digestion, provided they are supported in the use of these alternatives [41]. Such support should include standards and legal guidance for the existing formal and informal food redistribution mechanisms to address the associated liability risks for the food donor.

While the assistance of international agencies has been appreciated, a sustainable change will require (i) defined public sector incentives and support, (ii) guidance for solutions tailored to the local context (and not international examples) and (iii) ideally show financial gains. Only a small part of the business sector would change management practices because of social or environmental responsibility reasons, and in the same vein only a niche group of (mostly well-educated) green consumers is likely to support 'strong' prevention options as postulated by Mourad (2016) [42] or make green advertising a success [43].

However, sharing experiences via platforms within the retail and service sectors can also support awareness creation and peer pressure in view of social and environmental responsibilities. Of the four leading supermarket chains analyzed, so far two stressed in their annual reports their commitment to reducing their ecological footprint, in particular in view of greenhouse gases, using a comprehensive food waste management strategy.

Author Contributions: M.R. and P.D. co-prepared the manuscript including the revisions to it. M.A. undertook an additional literature review and revised the draft version. M.R. carried out the primary data collection and quantitative analysis. P.D. guided and supported the framing of the research, the development of data collection tools and contributed to manuscript preparation and the internal review of the paper. All three authors addressed the reviewer comments. All authors have read and agreed to the published version of the manuscript.

Funding: The study was financed by the Rural-Urban Linkages flagship of the CGIAR Research Program on Water, Land and Ecosystems (WLE) and a student scholarship from the Fiat Panis Foundation.

Institutional Review Board Statement: The study did not collect personal information and qualified for minimal risk exemption, aligned with Section 45 CFR 46.101(b) of the US Federal Policy for the Protection of Human Subjects as verified by IWMI's IRB.

Informed Consent Statement: Informed consent was obtained from all interviewees.

Acknowledgments: The authors would like to thank Andrea Knierim and Maria Gerster-Bentaya (University of Hohenheim), as well as Dehaja Senanayake and Felix Thiel for their guidance and support of the study. Thanks go also to FAO Sri Lanka for inspiring the study focus and the very helpful reviewers of the paper.

Conflicts of Interest: The authors declare no conflict of interest.

\section{References}

1. FAO. Global Food Losses and Food Waste_Extent, Causes and Prevention; FAO: Rome, Italy, 2011.

2. FAO. The State of Food and Agriculture 2019. In Moving forward on Food Loss and Waste Reduction; FAO: Rome, Italy, 2019; Available online: www.fao.org/3/ca6030en/ca6030en.pdf (accessed on 10 April 2020).

3. Kaza, S.; Yao, L.C.; Bhada-Tata, P.; Van Woerden, F. What a Waste 2.0: A Global Snapshot of Solid Waste Management to 2050; World Bank Urban Development: Washington, DC, USA, 2018; Available online: https:/ / openknowledge.worldbank.org/handle/1098 6/30317 (accessed on 27 November 2020).

4. NAPPP. Framework Development and Infrastructure Financing to Support Public Private Partnerships Environmental Assessment \& Management Framework (EAMF). 2018. Available online: http://documents1.worldbank.org/curated/en/9725915253338336 35/pdf/SFG4315-EA-REVISED-PUBLIC-disclosed-7-24-18.pdf (accessed on 15 December 2020).

5. NMC. Waste Management Strategy and Action Plan for Negombo City 2020-2030; Negombo Municipal Council: Negombo, Sri Lanka, 2020; Available online: https://www.iges.or.jp/en/publication_documents/pub/policysubmission/en/10993/Negombo_09 17_web.pdf (accessed on 10 December 2020).

6. Aheeyar, M.; Reitemeier, M.; Bucatariu, C.; Bandara, A.; Thiel, F.; Jayathilake, N.; Drechsel, P. Food waste in Sri Lanka: An Analysis of the Applicable Urban Regulatory Framework. Second Draft, Pending FAO Feedback. 2020. Available online: http:// waterdata.iwmi.org/Applications/sanitaion/reports/Report\%20Policy-\%20second\%20draft.pdf (accessed on 24 December 2020).

7. FAO. Partnering to Achieve Sustainable Food Security and Nutrition. 2019. Available online: http://www.fao.org/3/a-az497e.pdf (accessed on 2 April 2020). 
8. FAO; IWMI; RUAF Foundation. Food Waste Management in City Region Food System; Policy Brief; FAO: Rome, Italy; IWMI: Colombo, Sri Lanka, 2018; Available online: http:/ /www.fao.org/3/CA1110EN/ca1110en.pdf (accessed on 27 November 2020).

9. Japan International Cooperation Agency (JICA). Data Collection Survey on Solid Waste Management in Democratic Socialist Republic of Sri Lanka-Final Report; JICA, Kokusai Kogyo Co., Ltd.: Tokyo, 2016; Available online: https:/ /openjicareport.jica.go.jp/pdf/12 250213.pdf (accessed on 2 April 2020).

10. Karunarathna, A.; Singh, R.K.; Rajapaksha, T.; Premakumara, D.G.J.; Onogawa, K. State of Municipal Solid Waste Management in Negombo City, Sri Lanka; United Nations Environment Program: 2019. Available online: https://www.unenvironment.org/ietc/ resources/report/state-municipal-solid-waste-management-negombo-city-sri-lanka (accessed on 10 April 2020).

11. Otoo, M.; Fernando, S.; Jayathilake, N.; Aheeyar, M.; Madurangi, G. Opportunities for Sustainable Municipal Solid Waste Management Services in Batticoloa: Business Strategies for Improved Resource Recovery. In Final Report Submitted to the United Nations Office for Project Services (UNOPS); International Water Management Institute: Colombo, Sri Lanka, 2016; Available online: https:/ / publications.iwmi.org/pdf/H048062.pdf (accessed on 20 November 2020).

12. Sandaruwani, J.A.R.C.; Gnanapala, W.K.A.C. Food wastage and its impacts on sustainable business operations: A study on Sri Lankan tourist hotels. Procedia Food Sci. 2016, 6, 133-135. [CrossRef]

13. Ceylon Digest. How Much Food Do We Waste? 2020. Available online: https://www.ceylondigest.com/how-much-food-do-wewaste/ (accessed on 20 November 2020).

14. Cicatiello, C.; Blasi, E.; Giordano, C.; Martella, A.; Franco, S. "If only I Could Decide": Opinions of Food Category Managers on in-Store Food Waste. Sustainability 2020, 12, 8592. [CrossRef]

15. World Food Program, Sri Lanka-Country brief. 2020. Available online: https://www.wfp.org/countries/sri-lanka (accessed on 23 November 2020).

16. Global Hunger Index (GHI). Global Hunger Index by Severity. 2020. Available online: https:/ /www.globalhungerindex.org/ results.html (accessed on 23 November 2020).

17. Papargyropoulou, E.; Lozano, R.; Steinberger, J.K.; Wright, N.; Bin Ujang, Z. The food waste hierarchy as a framework for the management of food surplus and food waste. J. Clean. Prod. 2014, 76, 106-115. [CrossRef]

18. Närvänen, E.; Mesiranta, N.; Mattila, M.; Heikkinen, A. Introduction: A Framework for Managing Food Waste. In Food Waste Management; Närvänen, E., Mesiranta, N., Mattila, M., Heikkinen, A., Eds.; Palgrave Macmillan: Cham, Switzerland, 2020. [CrossRef]

19. Kumara, A.M.I.U.; Jayathilake, W.G.A.N.; Drechsel, P.; Fernando, S. Supermarket Food Waste and Current Waste Reduction, Resource Recovery and Reuse Practices-Case Study from Colombo Metropolitan Area, Sri Lanka. In Proceedings of the 23rd International Forestry and Environment Symposium 2018 of the Department of Forestry and Environmental Science, Nugegoda, Sri Lanka, 23-24 November 2016; p. 140. Available online: http://dr.lib.sjp.ac.lk/handle/123456789/8242 (accessed on 20 November 2020).

20. Eriksson, M. Supermarket Food Waste for Reduced Carbon Footprint. Ph.D. Thesis, University of Uppsala, Uppsala, Sweden, 2015. Available online: https:/ / pub.epsilon.slu.se/12756/1/Eriksson_m_151029.pdf (accessed on 17 November 2020).

21. Chalak, A.; Abou-Daher, C.; Chaaban, J.; Abiad, M.G. The global economic and regulatory determinants of household food waste generation: A cross-country analysis. Waste Manag. 2016, 48, 418-422. [CrossRef] [PubMed]

22. Fattibene, D.; Recanati, F.; Dembska, K.; Antonelli, M. Urban Food Waste: A Framework to Analyse Policies and Initiatives. Resources 2020, 9, 99. [CrossRef]

23. Hebrok, M.; Boks, C. Household food waste: Drivers and potential intervention points for design-An extensive review. J. Clean. Prod. 2017. [CrossRef]

24. De Laurentiis, V.; Caldeira, C.; Serenella, S. No time to waste: Assessing the performance of food waste prevention actions. Resour. Conserv. Recycl. 2020, 161, 104946. [CrossRef] [PubMed]

25. Silvennoinen, K.; Heikkilä, L.; Katajajuuri, J.-M.; Reinikainen, A. Food waste volume and origin: Case studies in the Finnish food service sector. Waste Manag. 2015, 46, 140-145. [CrossRef] [PubMed]

26. Abdelaal, A.H.; McKay, G.; Mackey, H.R. Food waste from a university campus in the Middle East: Drivers, composition, and resource recovery potential. Waste Manag. 2019, 98, 14-20. [CrossRef] [PubMed]

27. Derqui, B.; Fayos, T.; Fernandez, V. Towards a More Sustainable Food Supply Chain: Opening up Invisible Waste in Food Service. Sustainability 2016, 8, 693. [CrossRef]

28. Ofei, K.T.; Werther, M.; Thomsen, J.D.; Holst, M.; Rasmussen, H.H.; Mikkelsen, B.E. Reducing Food Waste in Large-Scale Institutions and Hospitals: Insights from Interviews with Danish Foodservice Professionals. J. Foodserv. Bus. Res. 2015, 18, 502-519. [CrossRef]

29. USEPA. A Guide to Conducting and Analyzing a Food Waste Assessment. 2014. Available online: https:/ /19january2017snapshot. epa.gov/sites/production/files/2015-08/documents/r5_fd_wste_guidebk_020615.pdf (accessed on 24 December 2020).

30. USEPA. Reducing Wasted Food \& Packaging: A Guide for Food Services and Restaurants. 2014. Available online: https: //19january2017snapshot.epa.gov/sites / production/files/2015-08/documents/reducing_wasted_food_pkg_tool.pdf (accessed on 24 December 2020).

31. Aiello, G.; Enea, M.; Muriana, C. Economic benefits from food recovery at the retail stage: An application to Italian food chains. Waste Manag. 2014, 34, 1306-1316. 
32. Georganas, A.; Giamouri, E.; Pappas, A.C.; Papadomichelakis, G.; Galliou, F.; Manios, T.; Tsiplakou, E.; Fegeros, K.; Zervas, G. Bioactive Compounds in Food Waste: A Review on the Transformation of Food Waste to Animal Feed. Foods 2020, 9, 291. [CrossRef]

33. Green Council. FoodWaste Lean and Green Label Scheme. 2020. Available online: https://www.greencouncil.org/fwlng (accessed on 20 December 2020).

34. Fernando, N.; Silva, M. Municipal Solid Waste Governance in Sri Lanka: A Literature Review. R4D Project Working Paper 1. University of Colombo, Colombo, 2020. Available online: https:/ /serval.unil.ch/resource/serval:BIB_2C8D8439993B.P001/REF (accessed on 2 April 2020).

35. Manapperuma, N.; (Director, Western Province Waste Management Authority, Colombo, Sri Lanka). Personal communication, 2019.

36. Jayathilake, N.; Drechsel, P. Organic Waste System Assessment Kaduwela Municipal Council. In Report for the DFAT-Funded Project "From Urban Waste to Sustainable Value Chains: Linking Sanitation and Agriculture through Innovative Partnerships"; International Water Management Institute: Colombo, Sri Lanka, 2020; (Unpublished Report).

37. European Union (EU). EU Actions against Food Waste. 2020. Available online: https://ec.europa.eu/food/safety/food_waste/ eu_actions_en (accessed on 17 November 2020).

38. FAO. FAO and the Ministry of Megapolis and Western Development Launch Project on Food Waste Reduction in Sri Lanka. Join in 2019. Available online: http:/ / www.fao.org/srilanka/news/detail-events/en/c/1203083/ (accessed on 24 November 2020).

39. Giordano, C.; Falasconi, L.; Cicatiello, C.; Pancino, B. The role of food waste hierarchy in addressing policy and research: A comparative analysis. J. Clean. Prod. 2020, 252. [CrossRef]

40. Sinnathamby, V.; Paul, J.; Dasanayaka, S.W.S.B.; Gunawardena, S.; Fernando, S. Factors affecting sustainability of municipal solid waste composting projects in Sri Lanka. In Proceedings of the 1st International Research Conference iNCOTeM, Moratuwa, Sri Lanka, 27 December 2016; Available online: https://www.researchgate.net/publication/312493252 (accessed on 10 December 2020).

41. Broad Leib, E.; Sandson, K.; Macaluso, L.; Mansell, C. Organic Waste Bans and Recycling Laws to Tackle Food Waste. BioCycle, 2018. Available online: https:/ / www.biocycle.net/organic-waste-bans-recycling-laws-tackle-food-waste (accessed on 27 November 2020).

42. Mourad, M. Recycling, recovering and preventing "food waste": Competing solutions for food systems sustainability in the United States and France. J. Clean. Prod. 2016, 126, 461-477. [CrossRef]

43. Shrum, L.J.; McCarty, J.A.; Lowrey, T.M. Buyer characteristics of the green consumer and their implications for advertising strategy. J. Advert. 1995, 24, 71-82. [CrossRef] 